Maritime Law

Volume I Arrest of Vessels 


\section{INTERNATIONAL BAR ASSOCIATION}

\section{Maritime Law \\ Volume I Arrest of Vessels}

Edited by

\section{LENNART HAGBERG}

with an introduction by

COLLIN McFADYEAN

Written by

Members of the Committee on Maritime and Transport Law

of the Section on Business Law

of the International Bar Association

Springer Science+Business Media, B.V. 1976 
ISBN 978-94-017-4435-5

ISBN 978-94-017-4433-1 (eBook)

DOI 10.1007/978-94-017-4433-1

Cover design: Pieter J. van der Sman

(C) 1976 Springer Science+Business Media Dordrecht

Originally published by Kluwer B. V., Deventer/The Netherlands in 1976

Softcover reprint of the hardcover 1st edition 1976

All rights reserved. No part of this publication may be reproduced, stored in a retrieval system, or transmitted in any form or by any means, electronic, mechanical, photocopying, recording or otherwise, without prior written permission of the publishers. 


\section{Table of Contents}

List of Contributors VII

Introduction IX

Editor's Note $\quad$ XI

Editor's Introduction XIII

About the International Bar Association XVII

Australia 1

Belgium $\quad 13$

$\begin{array}{ll}\text { Canada } & 17\end{array}$

Denmark $\quad 23$

Finland $\quad 27$

France $\quad 31$

Germany $\quad 35$

Greece $\quad 39$

Ireland $\quad 47$

Israel $\quad 51$

Malta $\quad 55$

Netherlands $\quad 59$

Norway $\quad 63$

$\begin{array}{ll}\text { Singapore } & 67\end{array}$

South Africa $\quad 73$

$\begin{array}{ll}\text { Sweden } & 81\end{array}$

United Kingdom $\quad 85$

United States of America $\quad 89$ 


\section{List of Contributors}

\section{Editor:}

Lennart Hagberg, advokat, Gothenburg.

\section{Contributors:}

Australia

by John de Koning, solicitor, Melbourne

Belgium

by Tony Kegels, advocat, Antwerpen

\section{Canada}

by John R. Cunningham, barrister and solicitor, Vancouver

Denmark

by E. Behrendt-Poulsen, højesteretssagfører, Copenhagen

Finland

by Henrik Langenskiöld, advokat, Helsinki

France

by Jacques Villeneau, avocat à la Cour, Paris

Germany

by Dr. H.-Chr. Albrecht, Hasche, Hamburg

Greece

by P. C. Panagopoulos of the Athens Bar, Athens

Ireland

by G. John Moloney, solicitor, Cork

Israel

by Peter Gad Naschitz, advocate, Tel Aviv 
Malta

by $\mathrm{R}$. Farrugia, solicitor, Birkirkara

The Netherlands

by Dr. F. Baron van der Feltz, advocat, Amsterdam

Norway

by Alex. Rein, høyesterettsadvokat, Oslo

Singapore

by T. H. A. Potts, advocate and solicitor, Singapore

South Africa

by $\mathrm{D}$. H. Sampson, solicitor, Durban

Sweden

by Robert Romlöv, advokat, Gothenburg

United Kingdom

by J. G. R. Griggs, solicitor, London

United States

by John C. McHose, attorney, Los Angeles 


\section{Introduction}

It is with great pleasure that as Chairman of the Section on Business Law of the International Bar Association I write this foreword to a series of handbooks on maritime law which have been prepared by the Committee on Maritime and Transport Law of our Section.

The first of these handbooks deals with 'Arrest of Vessels', the second with 'Enforced Sales of Vessels', the third with 'Registration of Vessels' and the fourth with 'Mortgages on Vessels'. I feel sure that they will all be valuable aids to international lawyers practising in the field of maritime law.

These handbooks owe their conception to Mr. Lennart Hagberg of Gothenburg, Sweden, the Chairman of the Maritime and Transport Law Committee. Both he and the contributors to the series have put an enormous amount of work into the handbooks and devoted long hours to their preparation, hours which I feel sure they have borrowed with difficulty from their heavy commitments as busy practising lawyers.

I am happy to think that our Section, which was formed only six years ago, is as its first ventures in the publishing field producing at the same time both these handbooks on maritime law and another on 'Contracts of Employment', which has been prepared by our Committee on Labour Law, under the chairmanship of Mr. Willard Z. Carr. Jr. of Los Angeles, California. May they be the forerunners of many more.

COLIN MCFADYEAN

London

June 1976 


\section{Editor's Note}

The Maritime and Transport Law Committee of the Section on Business Law of the International Bar Association has produced and the Section is now publishing, through the kind offices of Kluwer B.V., Deventer, The Netherlands, the first part of a handbook on maritime law. The second part will follow shortly.

As Chairman of the Committee I have been responsible for collecting and editing the material for the handbook and arranging for its publication.

The first two parts deal with the requirements for the arrest of vessels and their enforced sale respectively in the principal maritime countries. The third and fourth parts, still in the planning stage, will cover the registration of vessels and maritime liens and mortgages on vessels.

In preparing the first and second parts our first step was to send to the members of my Committee a list of specific questions as they related to their respective countries. On the basis of the answers received I prepared drafts for each country, which were sent to the contributors for revision and approval. I have tried to use uniform headings and to cover the same questions in the same manner and order but, because of differences in the legal systems concerned, it has not been possible to achieve absolute uniformity of lay-out.

The handbook, in each of its parts, attempts no more than to set out in general terms the main requirements under each legal system. Its purpose is to assist the practising lawyer to get an overall view which will prepare him for the requirements of whatever lawyer he may decide to consult in a foreign country.

It has been no part of our intention to prepare a full treatise in comparative law or to cover all questions which may arise. It is strongly recommended that in all cases a local lawyer be consulted; our handbook should not be used for a 'do it yourself' job, which could have disastrous consequences for the client. Nor do the Section on Business Law, the editor or the contributors assume any responsibility for the accuracy of the contents of the various articles.

I should like to express my thanks to the individual contributors for their efforts, to the Director-General of the International Bar Association Sir Thomas Lund for his encouragement, to his staff for their 
assistance and, last but not least, to Mr. J. G. R. Griggs of London who has read and revised most of the text.

Lennart Hagberg

June, 1976 


\section{Editor's Introduction}

As indicated in my note I have tried to use uniform headlines in order to assist the reader. I will now briefly set out the subjects intended to be covered under those headlines.

\section{Types of claims}

In some countries a vessel can only be arrested for claims secured by maritime liens or mortgages on vessels. In other countries a vessel can be arrested for any type of monetary claim. These questions are clarified under this headline.

\section{Evidence of Existence of a Claim}

The requirements to establish a claim as a basis for an arrest vary to a great extent. For the arrestor it is essential to know at the outset the requirements so far as evidence and documentation are concerned. Requirements of this sort are dealt with under this headline.

\section{Security}

For the arrestor it is vital to know whether it is necessary for him to put up security when arresting a vessel. In some countries no security is required. In other countries a limited bank guarantee is accepted but there are also countries where a cash deposit equal to the value of the vessel is required. The answers to such questions should be found here.

\section{Competent Court or Authority}

For the arrestor it is of course of importance to identify the authorities he will have to deal with when arresting a vessel. Country by country a description of the authorities involved will be found under this headline. 
Form for Application

In all countries a written application of some sort is required in order to achieve an arrest of a vessel. The particulars required vary from country to country. For that reason it is necessary to know country by country which particulars are necessary ingredients in such an application.

\section{Representation by Counsel}

In the Editor's Note I have strongly advised arrestors to instruct local counsel. The reader will find that in many countries representation by local counsel is necessary. I may add that here I have somewhat loosely used the word 'counsel' meaning a lawyer. Only very few countries in the world have the English divided profession of barristers and solicitors.

\section{Power of Attorney}

In a few countries a lawyer cannot represent a client before the authorities or the courts without having a written power of attorney. Such a requirement creates difficulties in arrest actions when time is of the essence. For that reason such a question must be clarified at the outset.

\section{Enforcement of Order of Arrest}

In some countries an arrest is automatically enforced. In other countries the arrestor must go to executory authorities and apply for enforcement. A description of the machinery for enforcement is found under this heading.

\section{Proceedings for Maintaining an Arrest}

It is vital for the arrestor to know whether he must initiate another set of proceedings in order to maintain an arrest. There is a fairly general rule country by country that an arrest will lapse unless the arrestor 
initiates proceedings in order to enforce his claim within a certain specified time. The time of course differs country by country. These specific requirements are clarified under this headline.

\section{Service of the Order of Arrest}

In most countries it is only necessary to serve the master. In other countries in addition the consulate in case of a foreign vessel must be notified and also the relevant register. There are also countries where Owners who are far from the place of arrest must be served. It is further universal that service must be complete in order to maintain the arrest. For that reason this is a vital subject dealt with under this headline.

\section{Difference in Treatment of National Vessels and Foreign Vessels}

Some countries are easy. There is no difference between national vessels and foreign vessels so far as arrest is concerned. In other countries national vessels may not be touched. There are also countries where it is very difficult to arrest a foreign vessel. Accordingly in choosing a suitable country for the arrest of a certain vessel this is an important question and the answers are intended to be found here.

\section{Time Element}

For economic reasons these days cargo vessels are equipped to load and discharge very quickly and only spend a few hours or at most one or two days in a port, when in the olden days vessels were lying peacefully for weeks and there was no rush to arrest. The contributions from the various countries indicate that the authorities are aware of this and that an arrest can be made within hours provided that the requisite paper work has been done.

\section{Convention on the Arrest of Vessels}

In the year of 1952 an International Convention was signed in Brussels in respect of Arrest of Seagoing Vessels. This Convention has 
been ratified by comparatively few maritime nations. None the less it is of importance for the arrestor to know whether the country of arrest has adopted that Convention or not.

\section{Immunity of State-owned Vessels}

In these days a considerable amount of governmental-owned vessels carry usual commercial cargoes. It is of utmost importance for an arrestor to know whether such a vessel can be arrested in the country where he is planning such a step. Already in the year of 1926 an International Convention was signed in respect of Immunity of Stateowned Vessels. Many of the maritime countries have incorporated the provisions of that Convention into their national laws. 


\section{About the International Bar Association}

The IBA, primarily an Association of Bar Associations and Law Societies, was founded in 1947. It is non-political and its objects are:

'To establish and maintain permanent relations and exchanges between Bar Associations throughout the world and their members.'

'To discuss problems of professional organisation and status.'

'To advance the study of practical and legal problems and to promote uniformity and definition in appropriate fields of law.'

'To promote the administration of justice under law among the peoples of the world.'

'In execution of these objects, to promote in their legal aspects the principles and aims of the United Nations and to co-operate with and promote co-ordination among international juridicial organisations having similar purposes.'

It seeks generally to:

1. ensure better co-operation between and improvement in the services of all Bar Associations and Law Societies;

2. provide opportunities for individual lawyers to make personal contacts and by sharing their expertise to contribute towards the solution of common international legal problems; and

3. enable the voice of the legal profession to be heard on the international scene and so to contribute towards the establishment and maintenance of the Rule of Law throughout the world.

The IBA has consultative status with the United Nations Organisation and the Council of Europe and has Standing Committees on United Nations Affairs and European Affairs.

It organises annually Conferences and seminars and publishes the International Bar Journal biannually and the International Business Lawyer quarterly. It also publishes Directories of its Members.

There are two sections of the IBA, the Section on Business Law set up to promote an interchange of information among Members as to laws, practices and procedures affecting business, financial and commercial activities throughout the world and the Section on General Practice whose members are engaged in the general practice of law. The Sections work on Business Law has 20 Committees and the 


\section{XVI}

Section on General Practice 15 which work mainly by mail but meet at least annually and more frequently if the Chairman is satisfied that there is a need for it. Most Committees are engaged in the study of specific subjects within the field of their activities.

78 Bar Associations and Law Societies belong to the IBA as well as approaching 4000 individual lawyers. Further details of the Association and how to join may be obtained from the IBA, 93 Jermyn Street, London SW1Y 6JE, England. 